\title{
JUDICIAL INDEPENDENCE AND JUdicial AdMinistration IN THE TOBIASS CASE
}

\section{Carl Baar}

Canada (Minister of Citizenship and Immigration) v. Tobiass ${ }^{1}$ arose out of a nationally-publicized incident in which a senior official of the Department of Justice Canada met with the Chief Justice of the Federal Court of Canada on 1 March 1996, and expressed concern about the slow movement of three citizenship-revocation proceedings against alleged war criminals. Over 18 months later, the Supreme Court of Canada concluded that the meeting compromised the appearance of judicial independence. In the process, the Court established as a matter of constitutional law the long-held convention that no government official should discuss a pending c ase with a judge without notice to counsel for the other parties. ${ }^{2}$

The decision constitutes a modest but important precedent in the growing body of case law on judicial independence in Canada. The unanimous reasoning of the Court is clear and direct, and integrates its holding into the larger context of judicial independence jurisprudence. At the same time, the case presents a wonderful opportun ity for analysis by students of judicial politics. It is possible to observe internecine conflicts within the Federal Court of Canada, and see how judges outside that court view its work.

More important to the welfare of the Canadian courts, however, is that Tobiass shows how much the judiciary as a whole suffers when judges with administrative respon sibilities do not discharge those responsibilities effectively. Tobiass represents primarily a failure in administration. When a failure in administration contributes to "a serious affront" to the appearance of judicial independence, ${ }^{3}$ it is time to consider how to prevent similar problems from arising in the future.

\section{THE HOLDING}

\footnotetext{
Canada (Minister of Citizenship and Immigration) v. Tobiass, [1997] 3 S.C.R. 391.

Ibid. at para. 74 .

Ibid. at para. 85 .
}

The Supreme Court's judgment has three parts, all presented by the Court on behalf of all nine members (the same nine justices that sat as a unit for over four years without a vacancy). The first part dealt with jurisdictional issues. Can an appeal courtentertain an appeal from astay ordered by a trial judge of the Federal Court in a Citizenship Act matter? The Supreme Court concluded that it had jurisdiction, since the appeal arose under the Federal Court Act, not the Citizenship Act. The second part dealt with the core issues around judicial independence: had a breach occurred? If so, what kind and how serio us? The third part dealt w ith whether a stay of proceedin gs was the appropria te remedy to an "affront" against judicial independence. (The Court never asked whether judicial independence had been violated, only whether a reasonable observer might perceive it had been "compromised"). ${ }^{4}$ This note will focus primarily on the second part of the Court's reasons.

Beginning with LeDain J.'s distinction in $R$. v. Valente $^{5}$ between individual and institutional independence, the Court states that Tobiass involves an issue of individual independence, or "personal independence," which the Court then equates with impartiality. ${ }^{6}$ The focus on individual independence is a reflection of the three respondents' argument ${ }^{7}$ that the March 1 meeting, and the subsequent exchange of correspondence between the federal official and the Chief Justice, constituted interference with the trial judge who was hearing their cases.

At the same time, however, the trial judge in these cases was the Associate Chief Justice of the Federal Court, and in that capacity he was the senior administrative judge of the Trial Division of the Federal

\footnotetext{
Ibid. at para. 70 .

R. v. Valente, [1985] 2 S.C.R. 673

Tobiass, supra note 1 at para. 68 .

Following Dickson C.J.'s definition of the core elements of individual independence setout in Beauregard v. Canada, [1986] 2 S.C.R. 56.
} 
Court. Thus the A.C.J. had assigned the cases in the first instance to himself, and the Chief Justice of the Federal Court, who presides in the Court of Appeal, would normally confer with the A.C.J. on an administrative matter that might co me to his attention involving the Trial Division. So there was an institutional dimension to the interaction between the two Chiefs that transcended but still significantly affected - the Associate Chief Justice's role as motions judge for the matters on appeal.

Conceptually, this dual role did not affect the Suprem e Court's reasoning. The Court chose to treat the judicial independence issue in its individual dimension. But the Court's view, and that of the Canadian Judicial Council, were clearly affected by their perception that the trialjudge's predicament was partly of his own making a product of the inadequate exercise of his own administrative responsibilities.

The Court concluded, with an infelicitous double negative, that there was "not sufficient evidence" that the Chief and Ass ociate Chief Justices "did not in fact remain independ ent." ${ }^{8}$ Thus the emphasis shifted to the appearance of independence, allowing the Court to apply its test from R. v. Lippé: "whether a well-informed and reasonable observer would perceive that judicial independence has been compromised." Conduct resulting in that perception would be considered an affront to judicial independence.

The third step in the argument reflected the federal official's status as a member of the bar. "There are many principles of professional conduct that must be observed in order to maintain the appearance of judicial independence," stated the Court, and "two of them are particularly relevant here." First, a judge and counsel in a particularcase should not meet without informing counsel for the other parties. While there is no formal code of ethics for judges (or lawyers), the Court c ited the late B.C. Chief Justice J. O. Wilson's 1980 Book for Judges (commissioned by the Canadian Judicial Council) in support of this principle. ${ }^{10}$ Second, as a general rule, a judge should not accede to the request of one party without a chance for the other parties to be heard. ${ }^{11}$

While the Court anchors its pronouncements in professional ethical standards that command broad support in Canada, its reasoning extends to any contact with government officials, whether elected politicians or

\footnotetext{
Tobiass, supra note 1 at para. 69.

Ibid. at para. 70 .

10 See J.O. Wilson, A Book for Judges (Ottaw a: Canadian Judicial Council, 1980) cited ibid. at para. 74 .

11 Ibid. at para. 75 .
}

career public servants, in analogous circumstances. The Court's reasoning suggests a presumption that ex parte commu nication with a government party compromises the appearance of individual independence. However, the Court's reasons in Tobiass also provide a compelling factual basis for the presumption in the instant cases. The Court notes that before 1 March 1996, the trial judge "resolved not to expedite consideration of the preliminary motions." ${ }^{12}$ After $1 \mathrm{M}$ arch, his conduct changed. "We do not see," the Court concluded, "how a reasonable observer could fail at least to wonder whether the government, through Mr. Thompson, had succeeded in influencing the Associate Chief Justice to take a position more favourable to the Government's interests than he would o therwise have done."13

This argument drives home the reasonableness of concluding that the March 1 meeting compromised the appearance of impartiality. But does it also mean that ex parte communication with government in a future case will not meet the reasonableness test - and will not compromise judicial independence — unless there is similar proof of a trial judge's change in position following the communication?

In summary, the Supreme Court found that the failure to observe two principles of professional conduct of lawyers and judges caused damage to the appearance of judicialindependence. But does this require that a stay of proceedings be entered? The Supreme Court con cludes in the negative. Since the Associate Chief Justice is no longer involved in the proceedings, and it was the appearance of individual not institutional independence that had been compromised, another judge of the Trial Division would be able to handle the cases. The cases themselves were deemed of sufficient importance that a stay order would not be just under the circumstances.

Thus the Court is able to have the best of both worlds. Judicial independence is vindicated, its underlying theory and constitutional basis elaborated upon, but without any further cost to the federal government's efforts to revoke the citizenship of three alleged war criminals. Who says hard cases make bad law?

\section{THE JUDICIAL POLITICS}

Three courts heard the stay applications: the Trial Division of the Federal Court, the Federal Court of Appeal, and the Supreme Court of Canada. Each of the

\footnotetext{
Ibid. at para. 76 .

Ibid. at para. 78 .
} 
three came to different conclusions on the central issue of judicial independence. The Trial Division judge concluded that a breach of judicial independence had occurred, and that a stay should be entered. Three justices of the Federal Court of Appeal concluded that no breach of judicial independence occurred, although one concluded that there had been the appearance of a breach. Finally, the Suprem e Court of Canada concluded unanimously that no breach occurred, but the appearance of judicial independence had been compromised.

Considering that the views expressed at the time of these events uniformly criticized the government, what accounts for these divergent interpretations of how the principle of judicial independence applies? The best explanation may derive from an understanding of the judicial politics surrounding the Federal Court and its administration. Professor Ian Bushnell's recentlypublished comprehensive history of the Federal Court of Canada concludes that the "tensions and frictions that exist between" the trial and appeal divisions of the Court exceed "those that would normally exist between a trial court and an appeal court. The history of the Federal Court, with its emphasis on there being only one court, has created this problem, which is unique within Canada."14

In theory, the Federal Court is a single court, with one chief justice and one administrator, and se niority measured from initial appointment to the Court (a carryover from the previous Exchequer Court). Thus a judge appointed to the appeal bench from the Trial Division may catapult over some sitting appeal court judges, "[a] source of irritation for some" of them. But the two divisions operate in practice "as sep arate courts," with the effects "felt more by the trial court judges, and many resent it. They tend to see the gulf between the divisions as the result more of the attitude of the members of the Appeal Division than of some inherent need for a separate existence." For several years after the 1984 election of the Mulroney government, no promotions were made, widening the existing g ulf. ${ }^{15}$

Bushnell's observations help explain variations in the judgments in Tobiass. Thus, Cullen J. of the Trial Division was quick to defend his Trial Division colleague, Associate Chief Justice James Jerome, and attack Chief Justice Julius Isaac of the Court of Appea 1. "Before [even] turning to the merits of this motion," said Cullen J., "I think it important to point out that neither this Court [namely, the Trial Division] nor the parties are aware of

\footnotetext{
14 I. Bushn ell, The Federal Court of Canada: A History, 1875-1992 (Toronto: University of Toronto Press, 1997) at 341.

15 Ibid. at 340 .
}

exactly what transpired during the meeting between the Chief Justice" and the Assistant Deputy Attorney Genera $1 .{ }^{16}$ This case, he asserted, "is about the liberty of an individual judge to hear and decide the cases, free of interference from the Chief Justice of the Federal Court or the Assistant D eputy A ttorney Ge neral." 17 "The influence or pressure that was brought to bear on the Associate Chief Justice is especially egregious, given that the statements were conveyed by the Chief Justice of the Federal C ourt." 18

Not only is the Chief Justice always the focus of blame for a situation in which "a reas onable person w ould believe there had been judicial interference and these three respondents would not be coming before an independent court," but the Associate Chief Justice is totally without fault in the incident: "There is no persuasive evidence in the record that the Associate Chief Justice was actually influenced or that he would have acted unfairly in any way." Nor could Cullen J. "conclude that the cases were progressing unusually slowly or that the Asso ciate Chief Justice was acting neg ligently." 19

The Court of Appeal had a much different view of the 1 March meeting and its aftermath: "The order made by the judge of first instance [Cullen J.] was ... as unwarranted as his indignation with the Chief Justice's behaviour." Cullen J.'s finding "that the references were proceeding normally before the Associate Chief Justice and that there was no legitimate reason justifying the Chief Justice's interv ention ... is patently wrong. The pace of the proceedings before the Associate Chief Justice had been so slow as to certainly give rise to a suspicion that justice was not rendered with reaso nable diligence." Thus the Chief Justice was "duty bound to intervene ... irrespective of the circumstances in which the information had been conveyed to him." 20 "There was no way for the Chief Justice to understand the reasons for this quite unusual delay without inquiring." 21 And "an y one who is familiar with the organization of the Federal Court and keeps in mind that the presiding judge was not a junior judge but the As sociate Chief Justice, the head of the Trial Division responsible for its day-to-day operation, would be at a loss to imagine that any pressu re could be exerted or any fear felt." 22

\footnotetext{
Canada v. Tobiass, 41 Admin. L.R.(2d) 272 at 278-79 (F.C.T.D.).

Ibid. at 282 .

Ibid. at 284 .

Ibid. at 282-83.

20 Canada (Citizensh ip \& Immigration)v. Tobiass, 142 D.L.R. (4th) 270 at $287-88$ (F.C.A.) (Pratte J.A. concurring).

21 Ibid. at 283 (per M arceau J.A.).

22 Ibid. at 280-81.
} 
The Supreme Court of Canada, not inclined to defend either the C.J. or the A.C.J., as their respective colleagues did in the two courts below, found fault with both. Thus the March 1 meeting was "clea rly inapprop riate ... despite the fact that the occasion for the meeting $w$ as a highly legitimate concern about the exceedingly slow progress of the cases." ${ }^{23}$ Criticisms of the Chief Justice, however, were rather mild, and criticisms of the Associate Chief Justice surprisingly s trong. "The Associa te Chief Justice's dilatoriness defies explanation," concluded the unanimous Court. ${ }^{24}$ Before March 1, 1996, the A.C.J. "insisted on hearing oral argum ent accord ing to the original, exceedingly dilatory s chedule." 25

This pattern parallels the findings and conclusions of a three-judge panel of the Canadian Judicial Council appointed to address the conduct of Chief Justice Isaac and Associate Chief Justice Jerome. The panel was chaired by a trial court chief, Chief Justice Benjamin Hewak of the Manitoba Court of Queen's Bench, and two appellate court chiefs, Associate Chief Justice John Morden of Ontario and Chief Justice Catherine Fraser of Alberta. The panel was set up by Chief Justice Allan McEachern of British Columbia, in his capacity as Chairman of the Council's Judicial Conduct Committee. The Isaac matter was taken up first, as a result of a specific complaint; no complaint had been received about Jerome, but "Mc Eachern requested that the Panel consider the matter because of widespread media and public attention to the allegations of serious delay." 26

Regarding Chief Justice Isaac, the panel concluded that while "the wording of your letter to Mr. Thompson was unfortunate and ... you should have taken the initiative to ensure that counsel for the Responden ts were informed of the discussions which had taken place, your conduct clearly does notwarrant even the consideration of your removal from the office of judge." Failure to notify counsel "was inappropriate but not serious." No formal investigation under the Judges Act "is warrante d." 27

The panel's findings about the March 1 meeting emphasized a number of background considerations that went beyond the three instant cases. One was an "institutional history of significant problem s of delay in the Trial Division" covering immigration applications, unemployment insurance appeals, access to information

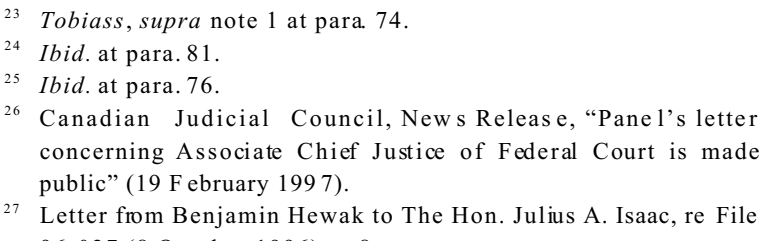

27 Letter from Benjamin Hewak to The Hon. Julius A. Isaac, re File 96-027 (8 October 1996) at 8 . litigation, and "[f]inally, the delay of $2 \frac{1}{2}$ years in rendering judgment by the trial judge in the Luitjens case... the first proceeding to revoke the citizenship of a person as a result of being investigated for war crimes." 28 This background legitimated both the Chief Justice's inquiry to the Associate Chief Justice following the March 1 meeting, and concem about the Associate Chief Justice's effectiveness as administrative head of the Trial Division.

Four months later, when the panel wrote Associate Chief Justice Jerome, it concluded that "you were jointly responsible with Chief Justice Isaac for ensuring that notice was given to the parties," but that "your conduct ... does not warran $t$ a recommendation for a formal investigation" under the Judges Act. ${ }^{29}$ Thus Jerome was held to share responsibility, in sharp contrast to Trial Division Justice Cullen's earlier reasoning. And the Associate Chief Justice was subject to additional criticism from the panel because his "handling of the conduct of the proceedings ... fell short of the standard of diligence which could reasonably be expected of a case management judge." 30

While the Canadian Judicial Council did not use language as strong as the Supreme Court in criticizing the Associate Chief Justice, the two bodies still seemed to share a common view of the Trial Division's shortcomings. In spite of this commonality, however, the Court and the Council still took jabs at one another in the public record. At the close of its reasons in Tobiass, the Supreme Court indicated that the Council should have withheld its comments on the conduct of Chief Justice Isaac until the Court rendered judgment. ${ }^{31}$ The Hewak panel responded on November 12, 1997, that it was "important that the obiter dicta of the Supreme Court of Canada ... not be adopted as the basis of an absolute rule by the Council in dealing with future complaints filed with it." While some complaints should be "held in abeyance," conduct iss ues in other situations may need to "be addressed expeditiou sly in spite of pending litigation. In the Panel's respectful view, that was certainly true in the matters before it." ${ }^{32}$

In summary, to the extent that media and professional reaction to the judicial independence issues raised in the Tobiass case tended to focus on the conduct of Chief

\footnotetext{
28 Ibid. at 4.

29 Letter from Benjamin Hewak to The Hon. James A Jerom e, re File 96-028 (18 Feb. 1997) at 5.

30 Ibid. at 4 .

1 Tobiass, supra note 1 at para. 118.

32 Letter from M s. Jeannie Thomas, Executive Director, Canadian Judicial Council to The Hon. A. Anne McLellan, Minister of Justice (12 November 1997) at 3.
} 
Justice Isaac rather than Associate Chief Justice Jerome, that reaction reenforced the Trial Division judiciary's view of its place within the Federal Court of Canada. To the extent that the Supreme Court of Canada and the Canadian Judicial Council saw the Chief Justice's conduct as an effort to overcome un acceptable delays, they w ere reflecting the Appellate Division jud iciary's view of life within the Federal Court. It is clear that judicial colleagues outside the Federal Co urt viewed Chief Justice Isaac's efforts more sympathetically than those of Associate Chief Justice Jerome. But beyond this embarrassing conflict, what can be learned aboutreducing the likelihood of future difficulties?

\section{DEALING WITH ADMINISTRATIVEFAILURE}

It is clear that the Trial Division of the Federal Court of Canada has a special set of administrative challenges. The Judicial Council panel noted in its letter to Jerome A.C.J. that his conduct of the proceedings "may be ... symptomatic of larger problems, possibly of a system ic nature... . [I]t is the Panel's view that procedural, administrative and even structural changes should be considered to encourage the more expeditious conduct of the Court's business and, ultimately, to provide better service to the public." ${ }^{33}$ In fact, a federal order-in-council of 30 May 1995, had asked the Office of the Auditor General to examine the possible regionalization and/or merger of the TrialDivision and the Tax Court of Canada, following a 1994 initiative by the Minister of Justice. The Auditor General tabled a substantial report on 2 April 1997. That report emphasizes potential cost savings in court support services, but does not deal with the distinctive structural problems that hinder expeditious case processing in the Trial Division. ${ }^{34}$

The Federal Court is the last court in Canada organized like the High Court of Justice in England. All of its judges reside in one location (Ottawa) and travel on circuit throughout the land to bring their specialized legal expertise to matters filed at local registries. For most of the twentieth century, the provinces of English Canada had similar central trial courts, sitting atop a judicial hierarchy that also included a set of county or district courts and a subordinate level of magistrate's courts. From 1975 to 1992, all nine provinces merged their supreme and county/district courts (at the same time upgrading their magistrate's courts to the Provincial Courts we know today). Thus small central trial courts with circuiting judges no longer exist, having been

\footnotetext{
33 Letter from Benjamin Hewak to The Hon. James A. Jerome (18 February 1997) at 4.

34 Office of the Auditor General of Canada, Report on the Federal Court of Canada and the Tax Court of Canada (Ottawa, 1997).
}

replaced by larger, more flexible, regionalized superior courts. New case flow management systems have developed that are com patible with this new generation of superior courts. In contrast, the Trial Division of the Federal Court still ope rates with the old mode 1, in the face of financial and organizational constraints of the late 1990s public sector.

While this distinctive structural challenge faces the Federal Court, its situation also requires consideration of a general issue raised quietly and consistently for the past 20 years: the appointment and term of chief justices. Chief justices and assoc iate chief justices, wh ether appo inted to superior courts under section 96 of the Constitution Act, or to federal courts under section 101, are appointed by government to serve during good behaviour. Unlike a university setting, where tenure accrues to a professors hip and where deans or other senior academic ad ministrators hold office for a fixed term and can then return to their tenured positions, chief justices hold office until age 75 (or until they are eligible for and choose to elect retirement). Yet the administrative responsibilities of chief justices and associate chiefjustices have grown in volume and variety as their courts have grown in size and complexity. It is more and more unrealistic to expect a judge to exercise those responsibilities throughout his or her career on the bench.

Steps have been taken under the Judges Act to provide for judicial positions that chief justices can opt to take after ten years, but there has been no initiative taken to establish a method for selecting chief justices and setting out their terms in a manner consistent with both administrative effectiveness and judicial independence.

Martin Friedland raised this issue in a separate chapter in his report on judicial independence and accountability. ${ }^{35}$ Justice Thomas G. Zuber raised the same issue a decade ago in his O ntario Courts Inquiry rep ort. ${ }^{36}$ Chief Justice Jules Deschênes raised the issue in his 1981 report, ${ }^{37}$ and Perry Millar and Carl Baar discussed it in a 1979 article. ${ }^{38}$ Yet the issue has never been given priority, in spite of the growing importance of chief justices' administrative work.

\footnotetext{
35 Martin L. Frie dland, A Place Apart: Judicial Independence and Accountability in Canada (Ottawa: Canadian Judicial Council, 1995) at 225-31.

36 Ontario Ministry of the Attorney General, Report of the Ontario Courts Inquiry (Toronto: Queen's Printer, 1987) at 247-48.

37 J. Deschênes, Masters in Their Own House: A Study on the Independent Judicial Administration of the Courts (Ottawa: Canadian Judicial Council, 1981) at 189-96.

38 Judge P.S. Millar and C. Ba ar, “A Management Philosophy for the Canadian Courts" (1979) 17 University of Western Ontario Law Review 218-19.
} 
The Trial Division of the Federal Court illustrates one set of consequences of the longevity and inflexibility of appointments as chief justice. Associate Chief Justice Jerome was appointed on 18 February 1980, by the Conservative Government of Prime Minister Joe C lark, the very day of the election which returne d the Libera ls to power under Pierre Trudeau. Jerome, a Liberal M.P., had been Speaker of the House of Commons beginning in 1974 and remained Speaker during the Clark G overnment. "It was an accepted practice in the political arena," writes Bushnell, "for the Speaker to choose a reward at the end of the term, provided of course that he or she had performed reasonably well (which Jerome had clearly done)." ${ }^{39}$ His experience as a litigator led him to favouran appointment to the Trial Division rather than to the Federal Court of Appeal, and the position of administrative head of the Trial Division was open.

Jerome's politicalsuccesses were sufficiently early in life that his judicial appointment came just two weeks shy of his 47 th birthday. As a result, he would need to serve over 18 years before being eligible for retirement (65 is the minimum age for a fed erally-appo inted judge to elect supernumerary status or to retire). His retirement option would not be available until 4 March 1998, and his exercise of any earlier option would have been defined as exceptional rather than normal and, therefore, more difficult at a time of controversy.

Limiting the length of a chief justice's term requires a method of appointment thatensures that the government of the day does not have the discretion to determine who sits as a chief justice. Otherwise, governments would be tempted, or at least perceived, to exercise indirect control over courts through a more frequently used power to appoint chief justices. In a number of provinces today, Chief Judges of Provincial Courts have limited terms, with appointment made directly by government, a practice that probably would be unconstitutional and surely inappropriate for federally-appointed chief justices.

It is time to consider new provisions for the appointment and terms of office of chief justices, associate chief justices, and (in Ontario) regional senior justices. Most of those who have examined the issue favour a fixed term, some with reappointment and some without. I would favour a single term of five or seven years, or perhaps a three-year term with the possibility of one renewal. Who should appoint? My preference is for election by the judges of the court, although it may be appropriate to expand the electorate to include

\footnotetext{
39 Bush nell, supra note 14 at 262.
}

participation of representatives of the bar and the ministries of justice.

It would also be appropriate to consider how to define and assign administrative responsibilities. The Federal Court, as Bushnell noted, is unique in designating an Associate Chief Justice as responsible for a Trial Division. In provincialsuperior courts, an Associate Chief Justice serves with the Chief Justice of the same court, and the A.C.J.'s responsibilities change over time. In the British Columbia Supreme Court, the current As sociate Chief Justice is responsible for the criminal lists in the court; the same practice was followed in the Quebec Superior Court when Jules Deschênes was Chief Justice and Kenneth Hugesson w as A.C.J. However, Deschênes' successor, Chief Justice Alan Gold, changed the division of responsibilities in the mid-1980 s. Gold defined his role as the court's chief executive officer and gave Associate Chief Justice Lawrence Poitras an expanded role as the court's chief operating officer.

As these examples suggest, a statutory division of responsibilities would be inappropriate, but some effort should be made within trial and appellate courts to spell out the roles and activities that need to be performed, and to ensure that they are performed. As theories of management expand in scope and ambition, our view of what was once the prosaic field of judicial administration may need to consider the functions of leadership as well as management, of strategic as well as operational planning, of client service and of case flow, as well as setting dates and staffing courtrooms.

Finally, in light of these considerations, the Canadian Judicial Counc il needs to consider its ow n monitorin g role in the operation of Canadian federal and superior courts. At this time, the Council focuses its oversight on the conduct of individual judges, and whether that conduct deserves criticism or should open an individual judge to the possibility of removal from office. But what if a court rather than an individual judge faces difficulties performing effectively? Disciplinary sanctions are hardly the best tools for promoting effective performance, but is there anything the Council can do collectively rather than ignore or watch helplessly the growing difficulties of one of its constituent courts?

The development of a Delays Project by the Council in the years following the 1990 Supreme Court judgment in $R$. v. $A s k o v^{40}$ and its aftermath is a useful step in the direction of increasing the Coun cil's role in assisting and enhancing the work of trial and appellate courts.

${ }^{40}$ R. v. Askov, [1990] 2 S.C.R. 1199. 
Developing a common data base so that courts can compare how well they are doing builds in a way to check whether, on this one measure of performance, individual courts are meeting an acceptable standard (or are improving, or are facing increased difficulty). More work is still necessary in this area, as well as in considering other performance measures. Council members need to be in a position to reenforce the efforts of their fellow chiefs, lest the performance problems of a particular court threaten the overall legitimacy of the judiciary as an institution.

\section{DISCUSSIONS BETWEEN GOVERNMENT AND JUDICIARY}

While the Tobiass judgment reenforces the strict separation in the formal legal relations between an individual judge and the parties with an interest in a particular pending case, the incident that gave rise to the case produces a mixed message. In fact, it is clear that in administrative matters chief justices and associate chief justices often deal with the same government officials who litigate in their courts. The same standards of isolation and formality do not apply, and cannot ap ply, if chief justices expect to carry out their responsibilities for example, to ens ure that their courts have ad equate resources and are able to anticipate changing caseloads, and to design case scheduling processes that ensure the smooth flow of cases through their courts.

The incident that compromised judicial independence in Tobiass occurred precisely because the administrative problems that had long characterized the TrialDivision of the Federal Court had intersected with the issues in a single case. At that point, as the Supreme Court of Canada put it directly and simply, "the actions of Isaac C.J. were more in the nature of a response to a party rather than a problem." Continued the Court: "an action that might have been innocuous and even obligatory under other circumstances acquired an air of improp riety as a result of the events that preceded it. Quite simply, it was inapprop riate." 41

The preservation of judicial independence thus requires that those judges with administrative responsibilities anticipate problems in their courts so that their inevitable dealings with government support rather than compromise the institutional independence that is a prerequisite for individual impartial adjudication in Canadian courts

\author{
Carl Baar \\ Department of Politics, Brock University.
}

